\title{
Research Career Programs, K-Series
}

National Cancer Institute

\section{Source}

National Cancer Institute. Research Career Programs, K-Series. NCI Thesaurus. Code C19786.

Grants designated with a K prefix and awarded to researchers who have a doctorate to develop their careers as independent scientists. Leng th of award can be from three and up to five years. Some are mentored the entire period whereas others are mentored partially or entirely unmentored. 